\title{
PENGARUH KUALITAS PRODUK BAJU BATIK HEM TERHADAP KEPUASAN PELANGGAN PADA HOME INDUSTRI BATIK SAHARA INDAH
}

\author{
Veta Lidya Delimah Pasaribu *) \\ Meko Yogi Suryo Prayoga**) \\ Email: vethalidya@yahoo.com*)
}

\begin{abstract}
ABSTRAK
Adapun tujuan dari penelitian ini adalah untuk mengetahui kualitas produk, mengetahui hubungan kualitas produk dan mengetahui kontribusi kualitas produk terhadap kepuasan pelanggan pada Home Industri Batik Sahara Indah.

Metode penelitian yang digunakan ialah metode deskriptif kuantitatif, observasi, wawancara, dokumentasi dan penyebaran angket (kuisioner) yang berisi 10 pernyataan terkait variabel kualitas produk dan 15 pernyataan terkait variabel kepuasan pelanggan kepada 98 responden yang juga merupakan pelanggan pada Home Industri Batik Sahara Indah.

Dari hasil analisa dengan menggunakan rumus koefisien korelasi product moment diperoleh $r=0,231$. Hal ini menunjukan adanya hubugan yang rendah antara Kualitas Produk Terhadap Kepuasan Pelanggan. Dari hasil perhitungan dengan menggunakan koefesien determinan hasilnya adalah $5,34 \%$. Hal ini berarti kepuasan pelanggan sebesar $94,66 \%$ dipengaruhi oleh faktor-faktor lain yang tidak termasuk dalam penelitian ini. Berdasarkan hasil uji signifikansi maka t-hitung $>$ t-tabel yaitu 2,390 > 1,660 yang artinya bahwa $\mathrm{HO}$ ditolak dan $\mathrm{Ha}$ diterima (signifikan), yaitu Kualitas Produk ( $X)$ mempunyai pengaruh signifikan terhadap tingkat Kepuasan Pelanggan ( $\mathrm{Y}$ ).Dari persamaan regresi yang diperoleh, $Y=44,943+0,354$ X.Dari persamaan terlihat bahwa koefisien $b$ bernilai positif, ini menunjukan bahwa perubahan $Y$ searah dengan perubahan $X$. Jadi nilai $Y$ akan meningkat jika nilai $X$ meningkat, sebaliknya nilai $Y$ akan menurun jika nilai $X$ menurun. Dengan demikian dapat disimpulkan bahwa Kualitas Produk berpengaruh positif terhadap Kepuasan Pelanggan pada Home Industri Batik Sahara Indah. Koefesien regresi $X=0,354$, maka skor variabel $Y$ akan bertambah 1 point dengan asumsi konstanta 44,943.
\end{abstract}

Kata Kunci: Kualitas Produk dan Kepuasan Pelanggan

\section{ABSTRACT}

The purpose of this study is to determine the quality of the product, know the relationship between product quality and determine the contribution of product quality to customer satisfaction at the Sahara Indah Batik Home Industry.

The research method used is quantitative descriptive method, observation, interview, documentation and questionnaire (questionnaire) which contains 10 statements related to product quality variables and 15 statements related to customer satisfaction variables to 98 respondents who are also customers of the Sahara Indah Batik Home Industry.

From the results of the analysis using the product moment correlation coefficient formula obtained $r=0.231$. This shows a low correlation between Product Quality and Customer Satisfaction. From the results of calculations using the determinant coefficient the result is $5.34 \%$. This means that customer satisfaction of $94.66 \%$ is influenced by other factors not included in this study. 
Based on the results of the significance test, $t$-count $t$-table is $2,390>1,660$, which means that $\mathrm{HO}$ is rejected and $\mathrm{Ha}$ is accepted (significant), namely Product Quality $(X)$ has a significant effect on the level of Customer Satisfaction $(Y)$. , $Y=$ $44,943+0,354 X$. From the equation, it can be seen that the coefficient $b$ is positive, this shows that the change in $Y$ is in line with the change in $X$. So the value of $Y$ will increase if the value of $X$ increases, otherwise the value $Y$ will decrease if the value of $X$ decreases. Thus it can be concluded that Product Quality has a positive effect on Customer Satisfaction at Batik Sahara Indah Home Industry. Regression coefficient $X=0.354$, then the variable $Y$ score will increase by 1 point assuming a constant of 44.943 .

Keywords: Product Quality and Customer Satisfaction

\section{A. Latar Belakang}

Batik adalah salah satu hasil murni karya bangsa indonesia yang terus berkembang secara turun menurun dan sudah mendapat pengakuan resmi secara Internasional. Di Indonesia batik adalah hasil produksi yang menjadi komoditas utama perdagangan antar daerah ke daerah dan juga sebagai komoditas utama ekspor terfavorit di indonesia.

Saat ini meskipun banyak pelanggan menemukan daya tarik dari mempunyai lebih banyak pilihan, tetapi kenyataannya kadang-kadang pelanggan dapat dibingungkan oleh banyaknya pilihan yang ditawarkan. Keadaan tersebut dikarenakan kondisi pasar yang telah mengalami perubahan yang disebabkan oleh perkembangan ekonomi dan teknologi yang sangat pesat.

Kepuasan pelanggana adalah sebagai suatu tingkatan dimana produk dirasakan sesuai dengan harapan pembeli. Kepuasan konsumen terhadap pembelian tergantung pada kinerja aktual produk tersebut, sehingga sesuai dengan harapan pembeli. Konsumen memiliki berbagai macam tingkatan kepuasan. Jika keberadaan suatu produk berada di bawah harapan pembeli, maka pembeli tersebut tidak merasa puas Kualitas produk sebagai evaluasi menyeluruh pelanggan atas kebaikan barang dan jasa. Isu utama dalam menilai kinerja produk adalah dimensi apa yang digunakan konsumen untuk mengevaluasinya. Keistimewaan suatu produk dapat dibagi kedalam dua bagian, yaitu keistimewaan atraktif dan keistimewaan langsung. Keistimewaan atraktif berkaitan dengan kepuasaan pelanggan yang di peroleh secara tidak langsung dari mengkonsumsi produk tersebut. Sedangkan keistimewaan langsung berkaitan dengan kepuasan pelanggan yang di peroleh secara langsung melalui mengkonsumsi produk yang memiliki karakteristik unggul seperti produk tanpa cacat, keandalan (reliability) dan lain-lainnya. (Gaspersz, 2011:7).

Batik Sahara Indah adalah Home Indutri Batik yang berada di daerah Pekalongan Jawa Tengah. Produk batik yang dihasilkan Batik Sahara Indah adalah berbahan dasar batik seperti: Batik hem, Blus, Kemeja, Longdress dll. Batik Sahara Indah berusaha meningkatkan dan mengatur strategi dalam kegiatan pemasaran dalam rangka meningkatkan penjualan produknya.

Berdasarkan uraian diatas, maka penulis tertarik untuk mengetahui lebih dalam tentang kualitas produk baju batik hem terhadap kepuasan pelanggan yang ada di Home Industri Batik Sahara Indah. Karena itu penulis tertarik untuk melakukan penelitian dengan judul:

"Pengaruh Kualitas Produk Baju Batik Hem Terhadap Kepuasan Pelanggan Pada Home Industri Batik Sahara Indah". 
B. Rumusan Masalah

1. Bagaimana kualitas produk baju batik Hem pada home industri batik Sahara Indah?

2. Bagaimana kepuasan pelanggan baju batik Hem pada home industri batik Sahara Indah

3. Seberapa besar pengaruh kualitas produk terhadap kepuasan pelanggan baju batik Hem pada home industri Sahara Indah?

\section{Tujuan Penelitian}

1. Untuk mengetahui kualitas produk baju batik Hem pada home industri batik Sahara Indah?

2. Untuk mengetahui kepuasan pelanggan baju batik Hem pada home industri batik Sahara Indah

3. Untuk menetahui seberapa besar pengaruh kualitas produk terhadap kepuasan pelanggan baju batik Hem pada home industri Sahara Indah?

\section{Landasan Teori}

Manajnemen adalah "proses perencanaan, pengorganisasian, kepemmpinan, dan pengendalian upaya anggota organisasi dan proses penggunaan semua sumber daya organisasi untuk tercapainya tujuan organisasi yang telah ditetapkan" . (Safroni, 2012:44)

Menurut Sapre dalam Usman (2013:6) "Manajemen adalah rangkaian kegiatan yang diarahkan langsung penggunaan sumber daya organisasi secara efektif dan efisien dalam rangka mancapai tujuan organisasi".

Pemasaran adalah sistem total aktivitas bisnis yang di rancang untuk merencanakan, menetapkan harga, mempromosikan dan mendistribusikan produk, jasa dan gagasan yang mampu memuaskan keinginan pasar sasaran dalam rangka mencapai tujuan organisasional.(Fandy Tjiptono, 2014:13).

Manajemen pemasaran terjadi ketika setidaknya satu pihak dalam sebuah pertukaran potensial berpikir tentang cara-cara untuk mencapai respons yang diinginkan oleh pihak lain.

Menurut Kotler dan Amstrong dalam buku Buchari Alma (2013:130) mendefinisikan bahwa "Manajemen Pemasaran adalah kegiatan menganalisa, memecahkan, mengimplementasikan dan mengawasi segala kegiatan (program) guna memperoleh tingkat pertukaran yang mengguntungkan dengan pembeli dalam rangka mencapai tujuan organisasi."

Kepuasan pelanggan adalah sebagai suatu tingkatan dimana produk dirasakan sesuai dengan harapan pembeli. Kepuasan konsumen terhadap pembelian tergantung pada kinerja aktual produk tersebut, sehingga sesuai dengan harapan pembeli. Konsumen memiliki berbagai macam tingkatan kepuasan. Jika keberadaan suatu produk berada di bawah harapan pembeli, maka pembeli tersebut tidak merasa puas.

Kualitas produk sebagai evaluasi menyeluruh pelanggan atas kebaikan barang dan jasa. Isu utama dalam menilai kinerja produk adalah dimensi apa yang digunakan konsumen untuk mengevaluasinya. Keistimewaan suatu produk dapat dibagi kedalam dua bagian, yaitu keistimewaan atraktif dan keistimewaan langsung. Keistimewaan atraktif 
berkaitan dengan kepuasaan pelanggan yang di peroleh secara tidak langsung dari mengkonsumsi produk tersebut. Sedangkan keistimewaan langsung berkaitan dengan kepuasan pelanggan yang di peroleh secara langsung melalui mengkonsumsi produk yang memiliki karakteristik unggul seperti produk tanpa cacat, keandalan (reliability) dan lain-lainnya. (Gaspersz, 2011:7).

\section{E. Metode Penelitian}

\section{Tempat Penelitian}

Penulis melakukan penelitian di Home Industri Batik Sahara Indah di JI Sapugarut Gg VII No. 320 Rt. 011Rw. 004 Buaran Pekalongan Jawa Tengah,Telp (0285) 4415088 / 085870110607.

2. Jenis Penelitian

Penelitian yang dilakukan penulis dalam menyusun skripsi ini adalah bersifat Deskriptif Kuantitatif, yaitu penulis ingin memberikan gambaran yang jelas tentang kualitas produk terhadap kepuasan pelanggan yang ada dalam perusahaan.

Menurut Sugiono (2011:11) "Penelitian kuantitatif dapat diartikan sebagai metode penelitian yang berdasarkan pada filsafat positivism, digunakan untuk meneliti pada populasi atau sampel tertentu".

\section{Populasi Dan Sample}

Penggertian Istilah sampel dan juga populasi tentunya sudah tidak asing lagi, peneliti menggunakan populasi serta sampel untuk mengetahui kondisi dari suatu wilayah.

Populasi yang diambil dalam penelitian ini yaitu pelanggan yang melakukan pembelian di Home Industri Batik Sahara Indah. Khususnya pelanggan baju batik hem di Batik Sahara Indah selama periode Januari s/d Maret 2018 sebanyak 98 pelanggan tetap yang tercatat di perusahaan.

Sampel adalah bagian dari jumlah dan karakteristik yang dimiliki oleh populasi. Setelah jumlah sampel yang akan di ambil dari populasi telah di tentukan selanjutnya pengambilan sampel ditentukan dalam bentuk sampling, Sugiyono (2011:115-116). Sampel yang baik adalah sampel yang memiliki populasi secara keseluruhan dengan rumus Slovin yaitu:

$$
n=\frac{N}{(1+N e)^{2}}
$$

$$
\begin{array}{ll}
\mathrm{n} & =\text { Jumlah Sampel } \\
\mathrm{N} & =\text { Jumlah Populasi } \\
\mathrm{e} & =\text { Tingkat Kesalahan }
\end{array}
$$

Tetapi metode digunakan dalam penelitian ini adalah sampling jenuh yaitu teknik pengambilan sampel bila semua anggota populasi diguunakan sebagai sampel, dalam penelitian ini berjumlah 98 orang atau responden. Selanjutnya Arikunto (2010:174) apabila kurang dari 100 lebih baik diambil semua sehingga penelitiannya merupakan penelitian populasi. Sehingga dalam penelitian ini jumlah sampel sama dengan populasinya yang berjumlah 98 pelanggan tetap yang tercatat di perusahan 


\section{F. Hasil dan Pembahasan Kesimpulan}

1. Kualitas produk baju batik hem yang dijual pada Home Industri Batik Sahara Indah secara keseluruhan hasilnya baik. Yaitu $50,10 \%$ yang menjawab baik, walaupun masih ada yang harus ditingkatkaan kembali khususnya pada kualitas produk yang akan dijual.

2. Kepuasan pelanggan baju batik hem pada Home Industri Batik Sahara Indah secara keseluruhan puas. Yaitu 42,99\% yang menjawab puas, walaupun masih ada yang harus di tingkatkan kembali khususnya dalam keramahan dalam melayani pelanggannya.

3. Terdapat pengaruh yang rendah antara Kualitas Produk Baju batik Hem Terhadap kepuasan Pelanggan pada Home Industri batik Sahara Indah Yaitu $Y=44,943+0,354 X, r=0,231, K D=5,34 \%$, thitung $>$ ttabel $(2,390>1,660)$.

\section{Saran}

Berdasarkan hasil penelitian dan pembahasan di BAB IV, maka disarankan : 1. Variabel Kualitas Produk Baju Batik Hem pada indikator keandalan (reliability) pada instrumen nomor 6, bahwa Home Industri Batik Sahara Indah harus meningkatkan kualitas produknya yang akan dijual.

2. Variabel Kepusan Pelanggan pada indikator Afektif pada instrumen nomor 6, bahwa Home Industri Batik Sahara Indah harus meningkatkan keramahan dalam malayani pelanggannya agar pelanggan sering berkunjung kembali ke Home Industri Batik Sahara Indah.

3. Dalam memperkuat pangsa pasar, manajemen Home Industri Batik Sahara Indah harus meningkatkan kualitas produknya,agar pelanggan sering berkunjung kembali dan berbelanja baju batik hem di Home Industri Batik Sahara Indah.

Perlu dilakukan penelitian lebih lanjut untuk mencari jawaban yang lebih mendalam mengenai kualitas produk terhadap kepuasaan pelanggan. Sehingga diharapkan pula dapat mengetahui adanya kemungkinankemungkinan ditemukannya variabel baru seperti variabel promosi, harga, tempat yang dapat mempengaruhi kepuasan pelanggan Home Industri Batik Sahara Indah.

\section{G. Daftar Pustaka} Cipta,

Arikunto. "Prosedur Penelitian Suatu Pendekatan Praktik", Rineka Jakarta, 2010.

Buchari, Alma. "Manajemen Pemasaran dan Pemasaran Jasa", CV Alfabeta

Bandung, 2013.

Danang Sunyoto. "Dasar-dasar Manajemen Pemasaran", cetakan pertama

CAPS, Yogyakarta, 2012 Ekonisia,

Deming, "Manajemen Kualitas produk dan Jasa", dalam Yamit,

Yogyakarta, 2010.

Dharmesta dan Irawan. "Manajemen Pemasaran Modern", Liberty, Yogyakarta

2012. 
Seto,

Effendi M, Guntur. "Transformasi Manajemen Pemasaran", Sagung

Jakarta, 2010.

Ghozali, Imam. "Aplikasi Analisis Multivariate dengan SPSS", Badan Penerbit

UNDIP, Semarang, 2011.

Scorecard

Gespersz. "Sistem Manajemen Kinerja Terintegrasi Balanced

dengan Malcolm Baldrige dan Lean Six Sigma Supply Chain Management", PT GramediaPustaka Utama, Jakarta, 2011. Maret",

Home Industri Batik Sahara Indah, "Annual Report bulan Januari -

Pekalongan 2018.

Herlambang, Susatyo. "Basic Marketing (Dasar-dasar Marketing)

Cara mudah

Memahami IImu Pemasaran", Gosyeng Publishing, Yogyakarta 2014.

Hurriyati Ratih. "Bauran Pemasaran dan Loyalitas Konsumen", CV Alfabeta,

Jakarta, 2010

Kotler dan Amstrong. "Principle Of Marketing",12th edition, Jilid 1 Terjemahan

Bob Sabran, Erlangga, Jakarta, 2014.

Kotler dan Keller. "Marketing Management", 15th Edition, Pearson Education,

Inc, 2016.

Kotler dan Amstrong. "Marketing an Introduction", Perason, Jakarta 2011. dan Citra

Kotler dan Amstrong dalam Kresnamurti. "Pengaruh Kualitas Produk

Merek Terhadap Loyalitas Konsumen". Jakarta, 2012.

Lailatul Fitriyah. "Pengantar Psikologi Umum", Prestasi Pustaka Jakarta, 2014

Mowen. “Akutansi Manajerial”, Salemba Empat, Jakarta, 2012.

Marwanto. "Marketing Sukses", Kobis, Yogyakarta, 2015.

Methods for

Sekaran, Uma. "Metodologi Penelitian untuk Bisnis (Research

Business)", Salemba, Jakarta, 2014.

Safroni. "Manajemen dan Reformasi Pelayanan Publik dalam Konteks

Birokrasi Indonesia", Aditya Media Publishing, Yogyakarta, 2012.

Sapre dalam Usman. "Manajemen”, Erlangga, Jakarta, 2013. Jakarta,

Sangadji. "Perilaku Konsumen dan Strategi Pemasaran", Erlangga,

2013.

2012.

Sunyoto. "Manajemen Sumber Daya Manusia", CAPS, Yogyakarta, Kualitatif,

Sugiyono. "Metode Penelitian Pendidikan Pendekatan Kuantitatif, dan R\&D, Alfabeta, Bandung, 2010.

Sugiyono. "Metode Penelitian Kuantitatif, Kualitatif dan R\&D", Bandung 2012.

Vol. 2 No.2 Februari 2019 
Sugiyono. "Metode Penelitian Bisnis", Alfabeta, Bandung, 2012.

Sugiyono. "Metode Penelitian Kuantitatif, Kualitatif dan R\&D", Afabeta, Bandung, 2013.

Sugiyono. "Metode Penelitian Kuantitatif, Kualitatif, dan Kombinasi (Mixed Methods), Alfabeta, Bandung, 2014.

Titik Wijayanti, “Marketing Plan”, dalam bisnis, PT. Elex Media Komputindo 